\title{
Role of proteasome-dependent protein degradation in long-term operant memory in Aplysia
}

\author{
Lisa C. Lyons, Jacob S. Gardner, Catherine E. Gandour, and Harini C. Krishnan \\ Department of Biological Science, Program in Neuroscience, Florida State University, Tallahassee, Florida 32306-4295, USA
}

\begin{abstract}
We investigated the in vivo role of protein degradation during intermediate (ITM) and long-term memory (LTM) in Aplysia using an operant learning paradigm. The proteasome inhibitor MG-132 inhibited the induction and molecular consolidation of LTM with no effect on ITM. Remarkably, maintenance of steady-state protein levels through inhibition of protein synthesis using either anisomycin or rapamycin in conjunction with proteasome inhibition permitted the formation of robust $24 \mathrm{~h} \mathrm{LTM}$. Our studies suggest a primary role for proteasomal activity in facilitation of gene transcription for LTM and raise the possibility that synaptic mechanisms are sufficient to sustain $24 \mathrm{~h}$ memory.
\end{abstract}

Paradoxically, while long-term memory formation requires new gene expression and protein synthesis, it may also require protein degradation. Protein degradation associated with synaptic plasticity or memory formation may be necessary for the activation of persistent kinase signaling pathways, removal of inhibitory signals, synaptic tagging or synaptic remodeling/ growth (Fioravante and Byrne 2011; Jarome and Helmstetter 2013, 2014). The ubiquitin-proteasome system (UPS) is highly conserved providing the primary mechanism for cytoplasmic protein degradation (Tai and Schuman 2008; Bach and Hegde 2016). The role of the proteasome in memory formation was initially postulated as necessary for removal of inhibitory constraints based upon research in the marine mollusk Aplysia californica (Chain et al. 1995; Hegde et al. 1997). Recent research has provided more specific insight into proteasome function, particularly during late hippocampal long-term potentiation in which proteasome activity affects new gene expression as well as modulating dendritic protein synthesis (Dong et al. 2008, 2014a,b; Hegde et al. 2014). However, despite widespread evidence linking the UPS to synaptic plasticity, questions still remain regarding the physiological functions of the proteasome in vivo during longterm memory (LTM) formation as several in vitro studies have shown that initial inhibition of proteasome activity strengthens synapses and enhances memory (Zhao et al. 2003; Dong et al. 2014a). As the mechanisms underlying memory formation are highly conserved, we investigated the role of proteasome function in vivo using $A$. californica.

Initially much of our understanding of the mechanisms underlying memory formation in Aplysia originated from research employing nonassociative learning paradigms either in vivo or in vitro (Byrne and Hawkins 2015), but recent research using associative operant learning paradigms in Aplysia has revealed the complexity of memory formation even in simple systems (Hawkins and Byrne 2015). In this study, we investigated the role of the ubiquitin-proteasome system in intermediate (ITM) and long-term memory (LTM) in Aplysia californica using the operant conditioning paradigm, learning that food is inedible (LFI). LFI memory represents a complex operant form of memory with plasticity observed in buccal ganglia neurons (Levitan et al. 2008; Michel et al. 2011a,b). Although the neurons involved in the feeding circuitry for appetitive and consummatory behaviors have been well-studied and many of the molecular signaling path-

\section{Corresponding author: lyons@bio.fsu.edu}

Article is online at http://www.learnmem.org/cgi/doi/10.1101//m.043794.116. ways underlying LFI memory have been identified (Katzoff et al. 2002, 2010; Cohen-Armon et al. 2004; Michel et al. 2011a,b, 2013) the specific neurons involved in LFI memory have not been identified. To further our understanding of the fundamental molecular mechanisms in LFI memory formation, we used a pharmacological approach to determine the role of the protein degradation. The open circulatory system of Aplysia allows in vivo behavioral pharmacology targeting all neurons involved in LFI memory including potential presynaptic, postsynaptic, and interneurons in the circuit. During LFI training, animals respond to netted seaweed with appetitive and consummatory feeding behaviors forming an association between the seaweed with failure of the swallowing attempts (Schwarz and Susswein 1986; Schwarz et al. 1991). Wild-caught A. californica, maintained in separate boxes within large seawater tanks at $15^{\circ} \mathrm{C}$, received LFI training using laver seaweed encased in tulle-mesh that elicited biting and swallowing attempts, but could not be physically swallowed. Training was discontinued starting at $25 \mathrm{~min}$ with the seaweed bag gently extracted from the mouth during a protraction cycle of the radula resulting in some minor variation in training times (Michel et al. 2012, 2013). As intermediate and long-term LFI memory are strongly regulated by the circadian clock (Lyons et al. 2005; Michel et al. 2013), training occurred at Zeitgeber Time 3 ( $3 \mathrm{~h}$ after lights on). The same protocol was used for testing continuing until the animal rejected the seaweed from the mouth for three consecutive minutes. Memory is denoted by significantly reduced total response time and the time the seaweed was retained in the mouth compared with naïve animals.

In Aplysia, nonassociative long-term facilitation requires the ubiquitin-proteasome system for removal of inhibitory proteins facilitating training-induced gene transcription and permitting the transition between short- and long-term memory (Hegde et al. 1997; Chain et al. 1999a,b). To determine whether associative LTM requires proteasome activity, animals were injected through the foot with the reversible proteasome inhibitor MG-132 (Lee and Goldberg 1996) 30 min prior to LFI training using the 25 min training protocol. MG-132 previously has been used to reversibly inhibit proteasomal activity in Aplysia ganglia

(C) 2016 Lyons et al. This article is distributed exclusively by Cold Spring Harbor Laboratory Press for the first 12 months after the full-issue publication date (see http://learnmem.cshlp.org/site/misc/terms.xhtml). After 12 months, it is available under a Creative Commons License (AttributionNonCommercial 4.0 International), as described at http://creativecommons. org/licenses/by-nc/4.0/. 
and cell cultures (Chain et al. 1999a; Khabour et al. 2002; Kurosu et al. 2007) as well as in mammalian hippocampal studies (Karpova et al. 2006; Hamilton et al. 2012; Forrest et al. 2013). No significant differences were seen in the training responses between animals injected with MG-132 (EMD BioSciences; $130 \mu \mathrm{L} /$ $100 \mathrm{~g}$ body weight of $0.5 \mathrm{mM}$ solution in DMSO for an approximate systemic concentration $1 \mu \mathrm{M}$ ) or vehicle (DMSO; $130 \mu \mathrm{L} /$ $100 \mathrm{~g}$ body weight) $30 \mathrm{~min}$ prior to training. Systemic drug concentrations were estimated using the proportion of the body weight attributed to the hemolymph, previously approximated as $65 \mathrm{~mL} / 100 \mathrm{~g}$ body weight (Levenson et al. 1999; Lyons et al. 2006). MG-132 injected $30 \mathrm{~min}$ prior to training completely blocked LTM when animals were tested $24 \mathrm{~h}$ after training with response times during testing of treated animals similar to naïve animals (Fig. 1A,B). Vehicle-injected animals displayed robust LTM with significant decreases observed in the total response time and the time the seaweed was retained in the mouth. MG-132 alone had no significant effect on baseline responses as animals injected with the drug and then tested $24 \mathrm{~h}$ later in the absence of training displayed responses comparable to naïve animals.

A

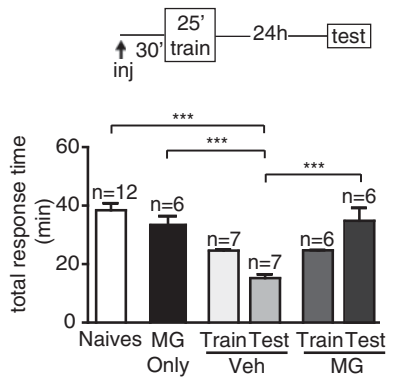

C
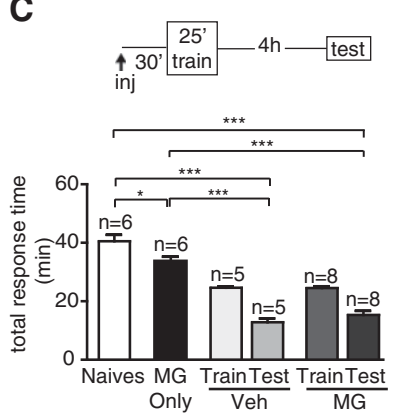

D
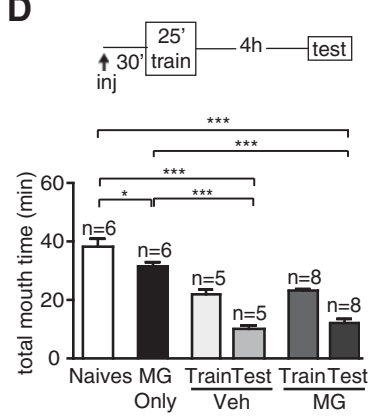

Figure 1. Long-term LFI memory, but not intermediate-term, requires proteasome activity. $(A, B) \mathrm{MG}-132$ was injected 30 min prior to LFI training to inhibit proteasome activity during the induction of LTM. No differences were observed in the training responses between groups 30 min after drug (Train MG) or vehicle injection (Train Veh). Inhibition of proteasome activity inhibited the induction of LTM with treated animals (Test MG) exhibiting $(A)$ total response times $\left(F_{(5,38)}=13.61 ; P<0.0001\right)$ and $(B)$ total mouth time $\left(F_{(5,38)}=11.10 ; P<0.0001\right)$ similar to naïve animals. Vehicle-injected animals (Test Veh) displayed robust LTM with significantly decreased responses during testing compared with naïve animals. MG-132 alone in the absence of training had no effect on behavioral responses $24 \mathrm{~h}$ after drug injection. Mean and SEM are plotted. Data analysis was performed using ANOVA followed by Bonferroni's multiple comparison test $(\mathrm{MCT})$. Asterisks denote significant differences with (***) $P<0.001$ and $\left({ }^{*}\right) P<0.05$. $(C, D)$. Inhibition of proteasome activity had no effect on ITM with treated animals (Test MG) showing significantly decreased $(C)$ total response times $\left(F_{(5,32)}=56.53 ; P<0.0001\right)$ and $(D)$ mouth times $\left(F_{(5,32)}=47.19 ; P<0.0001\right)$ compared with naïve and animals injected with MG-132 in the absence of LFI training (MG Only).
These results strongly suggest that the induction of long-term LFI memory requires proteasome activity.

In the past two decades, investigations of proteasome activity have centered on LTM with the role of the proteasome in ITM virtually unknown. Intermediate-term LFI memory extends $\sim 4-6 \mathrm{~h}$ after training (Michel et al. 2012); a timeframe similar to the temporal window of other forms of memory including late-LTP that require proteasome activity (Dong et al. 2008, 2014a,b; Hegde et al. 2014) and may be necessary for conversion of early-LTP into late-LTP and stabilization of synaptic strength (Cai et al. 2010). In mice, upregulation of the ubiquitin-proteasome system has been observed $4 \mathrm{~h}$ after taste learning (Rosenberg et al. 2016) and $6 \mathrm{~h}$ after training during the formation of social recognition memory (Jüch et al. 2009), a similar timeframe to the expression of intermediate-term LFI memory. For intermediate-term LFI memory, persistent PKA activity is required throughout the duration of memory expression (Michel et al. 2012) raising the possibility that proteasomal degradation of PKA regulatory subunits in the cytoplasm may be necessary for ITM. As the same LFI training protocol induces temporally separated and mechanistically distinct intermediate and long-term memory (Michel et al. 2012), we directly compared the role of proteasome activity in ITM with its role in LTM. MG-132 was injected 30 min prior to training with animals tested $4 \mathrm{~h}$ later for ITM. No significant differences were observed between groups during training. Approximately $5 \mathrm{~h}$ after drug injection, MG-132 alone resulted in a small, but significant, decrease in responses during testing compared with naïve animals. However, drug-injected trained animals demonstrated significantly decreased responses during testing compared with naïve or drug-injected untrained animals with response times comparable to trained vehicle-injected control animals (Fig. 1C,D). These results suggest that the critical role of the proteasome in LFI memory is not the degradation of proteins necessary for persistent cytoplasmic kinase activity or protein synthesis that are necessary for ITM, but instead is linked to processes specific to the formation of LTM such as the induction of new gene expression.

The period of molecular consolidation following training for LTM is characterized by macromolecular synthesis and encompasses a time in which memory is susceptible to disruption (Abel and Lattal 2001; Sweatt 2010). In Aplysia, persistent PKA activation is necessary for long-term facilitation involving proteasomal degradation of the type I regulatory subunit of PKA (Hegde et al. 1993; Chain et al. 1995, 1999a,b; Kurosu et al. 2007). During early molecular consolidation, long-term LFI memory also requires persistent PKA activity (Michel et al. 2011b) presumably resulting in its nuclear translocation, subsequent CREB phosphorylation followed by induction of gene transcription of the immediate early gene $A p C / E B P$ (Levitan et al. 2008). Consolidation of long-term memory in mammalian models also requires ubiquitin-proteasome-mediated protein degradation (Lopez-Salon et al. 2001; Artinian et al. 2008; Fioravante and Byrne 2011; Jarome et al. 2011; Jarome and Helmstetter 2014). Moreover, distinct windows of proteasome-dependent protein degradation have been found necessary for the consolidation of hippocampal-dependent object recognition memory (Figueiredo et al. 2015). In contrast, the inhibition of proteasome activity post-training enhances the consolidation of LTM in honeybees for olfactory conditioning (Felsenberg et al. 2014). To determine the time frame required for proteasome activity in long-term LFI memory, animals were injected with MG-132 either 1 or $4 \mathrm{~h}$ after LFI training. MG-132 treatment $1 \mathrm{~h}$ after training inhibited longterm memory with no decreases in response times observed upon testing compared with naïve animals or untrained animals injected with MG-132 (Fig. 2A,B). Thus, proteasomal-dependent protein degradation appears necessary during the period of 
A

B
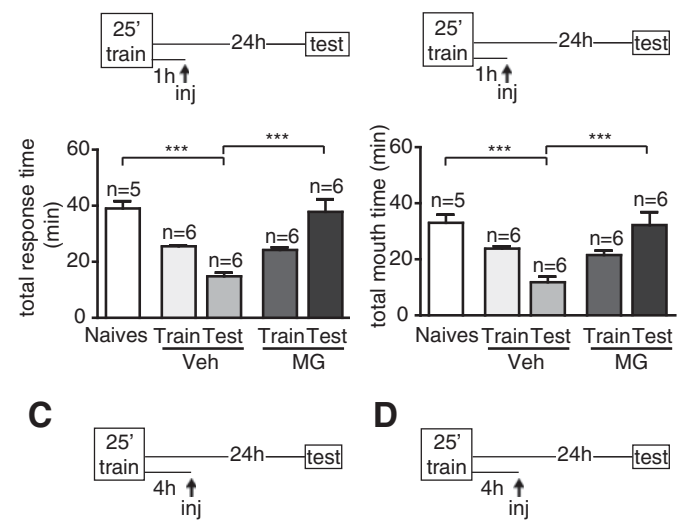

D
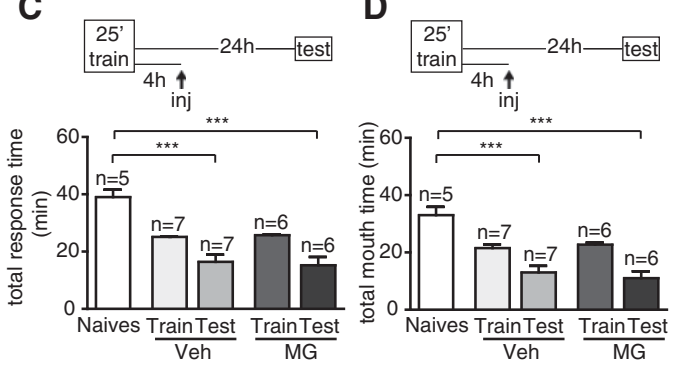

Figure 2. Proteasome activity is necessary post-training for the molecular consolidation of LTM. $(A, B)$ Injection of MG-132 $1 \mathrm{~h}$ post-training inhibited LTM with treated animals (Test MG) showing $(A)$ total response times $\left(F_{(4,24)}=17.04 ; P<0.0001\right)$ and $(B)$ mouth times $\left(F_{(4,24)}=\right.$ 10.08; $P<0.0001)$ similar to naïve animals. Vehicle-treated (Test Veh) animals exhibited LTM with significantly decreased response times during testing compared with naïve animals. Mean and SEM are plotted. Asterisks denote significant differences with $\left(^{* * *}\right) P<0.001$. $(C, D)$ Inhibition of proteasome activity $4 \mathrm{~h}$ post-training had no effect on LTM. Animals injected with MG-132 (Test MG) displayed robust LTM with significantly decreased $(C)$ total response times $\left(F_{(4,26)}=19.81\right.$; $P<0.0001)$ and $(D)$ mouth times $\left(F_{(4,26)}=17.50 ; P<0.0001\right)$ as compared with naïve animals. No differences were observed between the responses of treated animals with vehicle-injected animals during testing.

macromolecular synthesis for LFI memory. Molecular consolidation of $24 \mathrm{~h}$ LFI memory appears to last 3-4 h post-training with gene transcription no longer required $3 \mathrm{~h}$ post-training (data not shown) and protein synthesis no longer required $6 \mathrm{~h}$ after training (Levitan et al. 2010). Animals injected with MG-132 4 $\mathrm{h}$ after training exhibited significantly decreased response times and robust LTM comparable to vehicle-injected animals (Fig. $2 \mathrm{C}, \mathrm{D})$. Thus, the timeframe of required proteasome activity for $24 \mathrm{~h}$ memory appears to align with the requirements for new gene expression and protein synthesis. Our results are consistent with research investigating the role of the proteasome in late longterm potentiation (late-LTP; $3 \mathrm{~h}$ ) for which proteasome inhibition hinders CREB-mediated transcription and translation necessary for late-LTP (Dong et al. 2008). However, as later time points were not tested, it remains possible that longer forms of LFI memory, e.g., 48 or $72 \mathrm{~h}$ memory, that necessitate additional phases of protein synthesis (Levitan et al. 2010) also require additional periods of proteasome activity.

Intriguingly, while both protein synthesis and protein degradation are necessary for memory formation, the maintenance of steady-state protein levels through the inhibition of protein synthesis and protein degradation permits high-frequency stimulation-induced hippocampal late-LTP $(3 \mathrm{~h})$ in vitro (Fonseca et al. 2006). Recent research also showed that metabotropic glutamate receptor-mediated LTD requires protein synthesis to counteract a concurrent increase in proteasome-dependent protein degradation and that LTD can be induced when both translation and pro- teasome activity are simultaneously inhibited (Klein et al. 2015). To determine whether this type of steady state allows long-term operant memory formation in vivo, we inhibited protein synthesis using the reversible inhibitor anisomycin while simultaneously blocking proteasome activity with MG-132. Dual injection of anisomycin (Sigma-Aldrich; injected $1 \mathrm{~mL} / 100 \mathrm{~g}$ body weight of $0.666 \mathrm{mM}$ in artificial seawater for approximate system concentration of $10 \mu \mathrm{M}$ ) and MG-132 did not affect the baseline responses of the animals as treated animals displayed similar responses during training as vehicle-injected animals (dual injections of DMSO and artificial seawater; Fig. 3A,B). Remarkably, concurrent inhibition of protein synthesis and protein degradation permitted robust LTM similar to that observed in trained vehicle-injected animals. Animals injected with anisomycin and MG-132 presented significantly decreased response times in comparison to drugtreated animals that did not receive training (Fig. 3A,B). These results are surprising given the proposed role of proteasome activity in facilitating gene transcription necessary for LTM in multiple models (Hegde et al. 1997; Yamamoto et al. 1999; Dong et al. 2008; Fioravante et al. 2008).

During LTM formation, protein synthesis occurs both at the synapse and in the cell body (Sutton and Schuman 2006; Costa-Mattioli et al. 2009; Wang et al. 2009). Based upon its method of action as an inhibitor of peptidyltransferase and 80S ribosomal activity (Pestka 1972; Barbacid and Vazquez 1974; Gale et al. 1981), anisomycin inhibits synaptic and somatic protein synthesis as observed for facilitation in Aplysia cell cultures (Guan and Clark 2006). Local or synaptic protein synthesis appears to comprise a necessary component of LTM across learning paradigms. The mTOR pathway is hypothesized as a primary mechanism through which learning-induced synaptic protein synthesis is regulated across species (Costa-Mattioli et al. 2009; Gkogkas et al. 2010; Graber et al. 2013). Interestingly, proteasome activity may also modulate components of the mTOR pathway (Dong et al. 2014a). In Aplysia, the subset of transcripts translated via the TOR pathway comprises a high percentage of the transcripts in synaptic processes regulated by serotonin during facilitation (Casadio et al. 1999; Moccia et al. 2003). Rapamycin as an inhibitor of the TOR pathway inhibits synaptic protein synthesis necessary for long-term synaptic facilitation (Casadio et al. 1999; Moccia et al. 2003; Si et al. 2003; Carroll et al. 2004). Rapamycin-sensitive translation of ribosomal proteins at the synapse has been suggested as a mechanism for synaptic tagging for long-term memory (Moccia et al. 2003). Although rapamycindependent protein synthesis clearly plays a critical role in local protein synthesis, a role for somatic rapamycin-dependent protein synthesis in memory cannot be excluded. Rapamycin effectively inhibits intermediate- and long-term LFI memory (Michel et al. 2012) indicating the importance of the mTOR pathway in training-induced protein synthesis for LFI memory. Molecularly, rapamycin also inhibits the persistent phase of MAPK activity associated with intermediate and long-term LFI memory (Michel et al. 2011a, 2012).

Given the importance of local protein synthesis in LTM with an apparent bias toward rapamycin-dependent translation, we investigated whether rapamycin combined with proteasome inhibition permitted LTM. Animals were treated with rapamycin (EMD Biosciences; prepared as a $1 \mathrm{mM}$ DMSO stock solution, diluted to a $3.25 \mu \mathrm{M}$ working solution with artificial sea water, injected at 1 $\mathrm{mL} / 100 \mathrm{~g}$ body weight) and MG-132 prior to training and then tested $24 \mathrm{~h}$ later. The dual drug combination had no effect on training responses as no significant differences were observed between the groups. As with the combination of anisomycin and MG-132, dual treatment with rapamycin and MG-132 permitted LTM formation similar to vehicle-injected animals (paired injections of DMSO and ASW; Fig. 3C,D). The prevalence of 
A

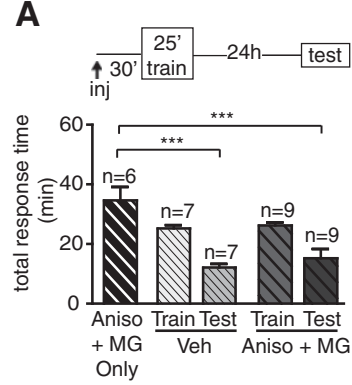

B

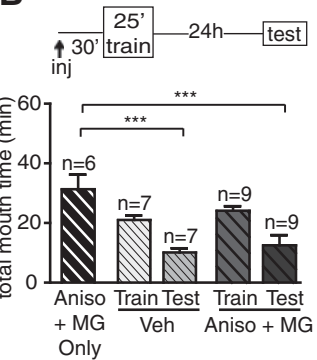

C

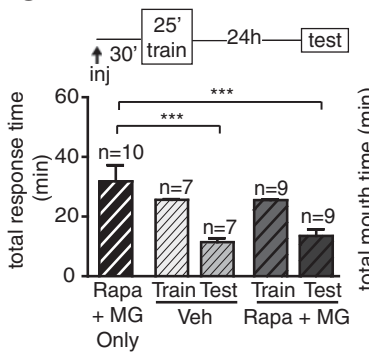

D

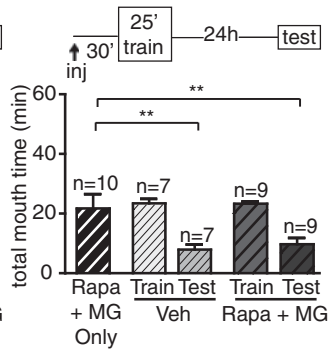

Figure 3. Concurrent inhibition of protein synthesis and protein degradation permits the induction of LTM. $(A, B)$ To determine whether simultaneous inhibition of protein synthesis and proteasome activity permitted the induction of LTM, animals were injected with anisomycin and MG-132 30 min prior to LFI training. Injection of the two drugs (Train Aniso $+\mathrm{MG}$ ) did not affect the training responses of the animals compared with vehicle-injected animals (Train Veh). Animals injected with both anisomycin and MG-132 (Test Aniso+MG) demonstrated clear LTM similar to vehicle-injected animals with animals showing significantly decreased (A) total response times $\left(F_{(4,28)}=14.82 ; P<0.0001\right)$ and $(B)$ mouth times $\left(F_{(4,28)}=10.34 ; \quad P<0.0001\right)$ as compared to drug-treated animals (Aniso+MG) that did not receive training. Data analysis was performed using ANOVA followed by Bonferroni's multiple comparison test (MCT). Asterisks denote significant differences with $\left(^{* * *}\right)$ $P<0.001$ and $\left({ }^{* *}\right) P<0.01$. $(C, D)$ Inhibiting protein synthesis using rapamycin along with blocking proteasome activity using MG-132 (approximate systemic concentration $1 \mu \mathrm{M}) 30$ min prior to LFI training permitted LTM. Injection of rapamycin with MG-132 did not affect the responses of the animals during training. Treated animals (Test Rapa+MG) displayed robust LTM with significant decreases in $(C)$ total response times $\left(F_{(4,31)}=8.64 ; P<0.0001\right)$ and $(D)$ time the seaweed was retained in the mouth $\left(F_{(4,31)}=7.513 ; P<0.0001\right)$ as compared with drug-treated (Rapa+MG) naives. Vehicle-injected animals exhibited comparable LTM.

rapamycin-sensitive translation in Aplysia processes suggests that maintenance of steady-state protein level at the synapse support $24 \mathrm{~h}$ LTM in our experiments, even though proteasome inhibition still persists in the cell body potentially limiting new gene transcription. Moreover, the compensatory mechanisms that permit LFI memory when both protein synthesis and protein degradation are inhibited also appear to bypass the need for persistent MAPK activity as the training-induced increase in MAPK signaling is blocked by rapamycin. One interpretation of these results is that the primary function of persistent MAPK during the molecular consolidation of LFI memory occurs not in the synapse but in the nucleus to facilitate gene transcription. If the inhibition of the proteasome through MG-132 was already limiting transcription, then limitations in transcription due to MAPK inhibition by rapamycin would be occluded. A proposed role for MAPK in facilitating gene transcription in LFI memory is consistent with previous research on long-term sensitization in which the inhibition of MAPK was found to block the training-induced increase in the immediate early gene and transcription factor ApC/EBP (Lyons et al. 2006). MAPK phosphorylation of CREB2 removes an inhib- itory constraint for CREB-dependent gene transcription in Aplysia (Michael et al. 1998). Furthermore, MAPK phosphorylation stabilizes $A p C$ /EBP limiting its degradation through proteasomal activity (Yamamoto et al. 1999) reinforcing the necessity of MAPK activity for learning-induced gene expression. We hypothesize that a similar situation occurred when animals were treated concurrently with anisomycin and MG-132 with the maintenance of synaptic protein levels providing a mechanism to compensate for limitations in gene transcription following training.

The above results and our interpretation suggest that proteasome activity is necessary for the induction and molecular consolidation of long-term LFI memory. Potentially, proteasome activity also may be required for synaptic growth or remodeling to maintain memory as proteasome activity may shape postsynaptic reorganization and the growth of new dendritic spines as shown in mammalian systems (Bingol and Schuman 2006; Bingol et al. 2010; Bingol and Sheng 2011; Hamilton et al. 2012). However, the limited requirement for proteasome activity following LFI training, e.g., no longer required $4 \mathrm{~h}$ after training, is earlier than the timeframe suggested for synaptic growth and the appearance of new varicosities for other learning paradigms in Aplysia (Kim et al. 2003; Bailey and Kandel 2008; Bailey et al. 2015). Longer lasting forms of LFI memory, e.g., 48 or $72 \mathrm{~h}$ memory, may require additional phases of proteasomal activity for pre- or postsynaptic remodeling. Although in vivo behavioral pharmacology cannot fully explain the necessary functions of the proteasome in long-term operant memory, these studies establish a base for future work at the cellular level and for investigations of longer forms of memory. Moreover, these studies raise the intriguing possibility of using synaptic compensation to strengthen neural circuits in circumstances when gene transcription is compromised thus permitting long-term memory formation and potentially providing insight into future therapies for neural disorders.

\section{Acknowledgments}

We thank Eric Noakes, Chelsea Organ, and Cassidy Lentsch for assistance with animal maintenance and behavioral experiments. This research was supported by National Institute of Mental Health grant R01MH81012 and National Institute of Neurological Disorders and Stroke grant R21NS088835.

\section{References}

Abel T, Lattal KM. 2001. Molecular mechanisms of memory acquisition, consolidation and retrieval. Curr Opin Neurobiol 11: 180-187.

Artinian J, McGauran AM, De Jaeger X, Mouledous L, Frances B, Roullet P. 2008. Protein degradation, as with protein synthesis, is required during not only long-term spatial memory consolidation but also reconsolidation. Eur J Neurosci 27: 3009-3019.

Bach SV, Hegde AN. 2016. The proteasome and epigenetics: zooming in on histone modifications. Biomol Concepts 7: 215-227.

Bailey CH, Kandel ER. 2008. Synaptic remodeling, synaptic growth and the storage of long-term memory in Aplysia. Prog Brain Res 169: 179-198.

Bailey CH, Kandel ER, Harris KM. 2015. Structural components of synaptic plasticity and memory consolidation. Cold Spring Harb Perspect Biol 7: a021758.

Barbacid M, Vazquez D. 1974. (3H)anisomycin binding to eukaryotic ribosomes. J Mol Biol 84: 603-623.

Bingol B, Schuman EM. 2006. Activity-dependent dynamics and sequestration of proteasomes in dendritic spines. Nature 441: 1144-1148.

Bingol B, Sheng M. 2011. Deconstruction for reconstruction: the role of proteolysis in neural plasticity and disease. Neuron 69: 22-32.

Bingol B, Wang CF, Arnott D, Cheng D, Peng J, Sheng M. 2010. Autophosphorylated CaMKII $\alpha$ acts as a scaffold to recruit proteasomes to dendritic spines. Cell 140: $567-578$.

Byrne JH, Hawkins RD. 2015. Nonassociative learning in invertebrates. Cold Spring Harb Perspect Biol 7. doi: 10.1101/cshperspect.a021675

Cai F, Frey JU, Sanna PP, Behnisch T. 2010. Protein degradation by the proteasome is required for synaptic tagging and the heterosynaptic 
stabilization of hippocampal late-phase long-term potentiation Neuroscience 169: 1520-1526.

Carroll M, Warren O, Fan X, Sossin WS. 2004. 5-HT stimulates eEF2 dephosphorylation in a rapamycin-sensitive manner in Aplysia neurites. J Neurochem 90: 1464-1476.

Casadio A, Martin KC, Giustetto M, Zhu H, Chen M, Bartsch D, Bailey CH, Kandel ER. 1999. A transient, neuron-wide form of CREB-mediated long-term facilitation can be stabilized at specific synapses by local protein synthesis. Cell 99: 221-237.

Chain DG, Hegde AN, Yamamoto N, Liu-Marsh B, Schwartz JH. 1995. Persistent activation of cAMP-dependent protein kinase by regulated proteolysis suggests a neuron-specific function of the ubiquitin system in Aplysia. J Neurosci 15: 7592-7603.

Chain DG, Casadio A, Schacher S, Hegde AN, Valbrun M, Yamamoto N, Goldberg AL, Bartsch D, Kandel ER, Schwartz JH. 1999a. Mechanisms for generating the autonomous cAMP-dependent protein kinase required for long-term facilitation in Aplysia. Neuron 22: 147-156.

Chain DG, Schwartz JH, Hegde AN. 1999b. Ubiquitin-mediated proteolysis in learning and memory. Mol Neurobiol 20: 125-142.

Cohen-Armon M, Visochek L, Katzoff A, Levitan D, Susswein AJ, Klein R, Valbrun M, Schwartz JH. 2004. Long-term memory requires polyADP-ribosylation. Science 304: $1820-1822$.

Costa-Mattioli M, Sossin WS, Klann E, Sonenberg N. 2009. Translational control of long-lasting synaptic plasticity and memory. Neuron 61: $10-26$.

Dong C, Upadhya SC, Ding L, Smith TK, Hegde AN. 2008. Proteasome inhibition enhances the induction and impairs the maintenance of late-phase long-term potentiation. Learn Mem 15: 335-347.

Dong C, Bach SV, Haynes KA, Hegde AN. 2014a. Proteasome modulates positive and negative translational regulators in long-term synaptic plasticity. J Neurosci 34: 3171-3182.

Dong C, Vashisht A, Hegde AN. 2014b. Proteasome regulates the mediators of cytoplasmic polyadenylation signaling during late-phase long-term potentiation. Neurosci Lett 583: 199-204.

Felsenberg J, Dyck Y, Kloß A, Dahlmann B, Kloetzel PM, Eisenhardt D. 2014. Two inhibitors of the ubiquitin proteasome system enhance long-term memory formation upon olfactory conditioning in the honeybee (Apis mellifera). J Exp Biol 217: 3441-3446.

Figueiredo LS, Dornelles AS, Petry FS, Falavigna L, Dargél VA, Köbe LM, Aguzzoli C, Roesler R, Schröder N. 2015. Two waves of proteasome-dependent protein degradation in the hippocampus are required for recognition memory consolidation. Neurobiol Learn Mem 120: $1-6$.

Fioravante D, Byrne JH. 2011. Protein degradation and memory formation. Brain Res Bull 85: 14-20.

Fioravante D, Liu RY, Byrne JH. 2008. The ubiquitin-proteasome system is necessary for long-term synaptic depression in Aplysia. J Neurosci 28: $10245-10256$.

Fonseca R, Vabulas RM, Hartl FU, Bonhoeffer T, Nägerl UV. 2006. A balance of protein synthesis and proteasome-dependent degradation determines the maintenance of LTP. Neuron 52: 239-245.

Forrest CM, Darlington LG, Stone TW. 2013. Involvement of the proteasome and caspase activation in hippocampal long-term depression induced by the serine protease subtilisin. Neuroscience 231: 233-246.

Gale EF, Cundliffe E, Reynolds PE, Richmond MH, Waring MJ. 1981. The concept. In The molecular basis of antibiotic action, 2nd ed. Wiley, London.

Gkogkas C, Sonenberg N, Costa-Mattioli M. 2010. Translational control mechanisms in long-lasting synaptic plasticity and memory. J Biol Chem 285: 31913-31917.

Graber TE, McCamphill PK, Sossin WS. 2013. A recollection of mTOR signaling in learning and memory. Learn Mem 20: 518-530.

Guan X, Clark GA. 2006. Essential role of somatic and synaptic protein synthesis and axonal transport in long-term synapse-specific facilitation at distal sensorimotor connections in Aplysia. Biol Bull 210: 238-254.

Hamilton AM, Oh WC, Vega-Ramirez H, Stein IS, Hell JW, Patrick GN, Zito K. 2012. Activity-dependent growth of new dendritic spines is regulated by the proteasome. Neuron 74: 1023-1030.

Hawkins RD, Byrne JH. 2015. Associative learning in invertebrates. Cold Spring Harb Perspect Biol 7. doi: 10.1101/cshperspect.a021709

Hegde AN, Goldberg AL, Schwartz JH. 1993. Regulatory subunits of cAMP-dependent protein kinases are degraded after conjugation to ubiquitin: a molecular mechanism underlying long-term synaptic plasticity. Proc Natl Acad Sci 90: 7436-7440.

Hegde AN, Inokuchi K, Pei W, Casadio A, Ghirardi M, Chain DG, Martin KC, Kandel ER, Schwartz JH. 1997. Ubiquitin C-terminal hydrolase is an immediate-early gene essential for long-term facilitation in Aplysia. Cell 89: 115-126.
Hegde AN, Haynes KA, Bach SV, Beckelman BC. 2014. Local ubiquitin-proteasome-mediated proteolysis and long-term synaptic plasticity. Front Mol Neurosci 7: 96.

Jarome TJ, Helmstetter FJ. 2013. The ubiquitin-proteasome system as a critical regulator of synaptic plasticity and long-term memory formation. Neurobiol Learn Mem 105: 107-116.

Jarome TJ, Helmstetter FJ. 2014. Protein degradation and protein synthesis in long-term memory formation. Front Mol Neurosci 7: 61.

Jarome TJ, Werner CT, Kwapis JL, Helmstetter FJ. 2011. Activity dependent protein degradation is critical for the formation and stability of fear memory in the amygdala. PLoS One 6: e24349.

Jüch M, Smalla KH, Kähne T, Lubec G, Tischmeyer W, Gundelfinger ED, Engelmann M. 2009. Congenital lack of nNOS impairs long-term social recognition memory and alters the olfactory bulb proteome. Neurobiol Learn Mem 92: 469-484.

Karpova A, Mikhaylova M, Thomas U, Knöpfel T, Behnisch T. 2006. Involvement of protein synthesis and degradation in long-term potentiation of Schaffer collateral CA1 synapses. J Neurosci 26: $4949-4955$.

Katzoff A, Ben-Gedalya T, Susswein AJ. 2002. Nitric oxide is necessary for multiple memory processes after learning that a food is inedible in Aplysia. J Neurosci 22: 9581-9594.

Katzoff A, Miller N, Susswein AJ. 2010. Nitric oxide and histamine signal attempts to swallow: a component of learning that food is inedible in Aplysia. Learn Mem 17: 50-62.

Khabour O, Lyons LC, Levenson J, Kategaya LS, Nguyen V, Eskin A. 2002. Signaling pathways involved in long-term regulation of glutamate uptake in Aplysia. Neuroscience Meeting Planner, Orlando, FL: Society for Neuroscience Online.

Kim JH, Udo H, Li HL, Youn TY, Chen M, Kandel ER, Bailey CH. 2003. Presynaptic activation of silent synapses and growth of new synapses contribute to intermediate and long-term facilitation in Aplysia. Neuron 40: $151-165$.

Klein ME, Castillo PE, Jordan BA. 2015. Coordination between translation and degradation regulates inducibility of mGluR-LTD. Cell Rep doi: 10.1016/j.celrep.2015.02.020.

Kurosu T, Hernández AI, Schwartz JH. 2007. Serotonin induces selective cleavage of the PKA RI subunit but not RII subunit in Aplysia neurons. Biochem Biophys Res Commun 359: 563-567.

Lee DH, Goldberg AL. 1996. Selective inhibitors of the proteasome-dependent and vacuolar pathways of protein degradation in Saccharomyces cerevisiae. J Biol Chem 271: 27280-27284.

Levenson J, Byrne JH, Eskin A. 1999. Levels of serotonin in the hemolymph of Aplysia are modulated by light/dark cycles and sensitization training. J Neurosci 19: 8094-8103.

Levitan D, Lyons LC, Perelman A, Green CL, Motro B, Eskin A, Susswein AJ. 2008. Training with inedible food in Aplysia causes expression of C/EBP in the buccal but not cerebral ganglion. Learn Mem 15: 412-416.

Levitan D, Twitto R, Levy R, Lyons LC, Susswein AJ. 2010. A brief retraining regulates the persistence and lability of a long-term memory. Learn Mem 17: $402-406$

Lopez-Salon M, Alonso M, Vianna MR, Viola H, Mello e Souza T, Izquierdo I, Pasquini JM, Medina JH. 2001. The ubiquitin-proteasome cascade is required for mammalian long-term memory formation. Eur J Neurosci 14: $1820-1826$.

Lyons LC, Rawashdeh O, Katzoff A, Susswein AJ, Eskin A. 2005. Circadian modulation of complex learning in diurnal and nocturnal Aplysia. Proc Natl Acad Sci 102: 12589-12594.

Lyons LC, Collado MS, Khabour O, Green CL, Eskin A. 2006. The circadian clock modulates core steps in long-term memory formation in Aplysia. J Neurosci 26: 8662-8671.

Michael D, Martin KC, Seger R, Ning MM, Baston R, Kandel ER. 1998. Repeated pulses of serotonin required for long-term facilitation activate mitogen-activated protein kinase in sensory neurons of Aplysia. Proc Natl Acad Sci 95: 1864-1869.

Michel M, Green CL, Eskin A, Lyons LC. 2011a. PKG-mediated MAPK signaling is necessary for long-term operant memory in Aplysia. Learn Mem 18: 108-117.

Michel M, Green CL, Lyons LC. 2011b. PKA and PKC are required for long-term but not short-term in vivo operant memory in Aplysia. Learn Mem 18: 19-23.

Michel M, Green CL, Gardner JS, Organ CL, Lyons LC. 2012. Massed training-induced intermediate-term operant memory in Aplysia requires protein synthesis and multiple persistent kinase cascades. J Neurosci 32: 4581-4591.

Michel M, Gardner JS, Green CL, Organ CL, Lyons LC. 2013. Protein phosphatase-dependent circadian regulation of intermediate-term associative memory. J Neurosci 33: 4605-4613.

Moccia R, Chen D, Lyles V, Kapuya E, E Y, Kalachikov S, Spahn CM, Frank J, Kandel ER, Barad M, et al. 2003. An unbiased cDNA library prepared from isolated Aplysia sensory neuron processes is 
enriched for cytoskeletal and translational mRNAs. J Neurosci 23: 9409-9417.

Pestka S. 1972. Studies on transfer ribonucleic acid-ribosome complexes. XIX. Effect of antibiotics on peptidyl puromycin synthesis on polyribosoms from Escherichia coli. J Biol Chem 247: 4669-4678.

Rosenberg T, Elkobi A, Dieterich DC, Rosenblum K. 2016.

NMDAR-dependent proteasome activity in the gustatory cortex is necessary for conditioned taste aversion. Neurobiol Learn Mem 130 7-16.

Schwarz M, Susswein AJ. 1986. Identification of the neural pathway for reinforcement of feeding when Aplysia learn that food is inedible. J Neurosci 6: 1528-1536.

Schwarz M, Feldman E, Susswein AJ. 1991. Variables affecting long-term memory of learning that a food is inedible in Aplysia. Behav Neurosci 105: 193-201.

Si K, Giustetto M, Etkin A, Hsu R, Janisiewicz AM, Miniaci MC, Kim JH, Zhu H, Kandel ER. 2003. A neuronal isoform of CPEB regulates local protein synthesis and stabilizes synapse-specific long-term facilitation in Aplysia. Cell 115: 893-904.
Sutton MA, Schuman EM. 2006. Dendritic protein synthesis, synaptic plasticity, and memory. Cell 127: 49-58.

Sweatt JD. 2010. Mechanisms of memory, 2nd ed. Academic Press/Elsevier

Tai HC, Schuman EM. 2008. Ubiquitin, the proteasome and protein degradation in neuronal function and dysfunction. Nat Rev Neurosci 9: 826-838.

Wang DO, Kim SM, Zhao Y, Hwang H, Miura SK, Sossin WS, Martin KC. 2009. Synapse- and stimulus-specific local translation during long-term neuronal plasticity. Science 324: 1536-1540.

Yamamoto N, Hegde AN, Chain DG, Schwartz JH. 1999. Activation and degradation of the transcription factor $\mathrm{C} / \mathrm{EBP}$ during long-term facilitation in Aplysia. J Neurochem 73: 2415-2423.

Zhao Y, Hegde AN, Martin KC. 2003. The ubiquitin proteasome system functions as an inhibitory constraint on synaptic strengthening. Curr Biol 13: 887-898.

Received August 21, 2016; accepted in revised form October 24, 2016. 


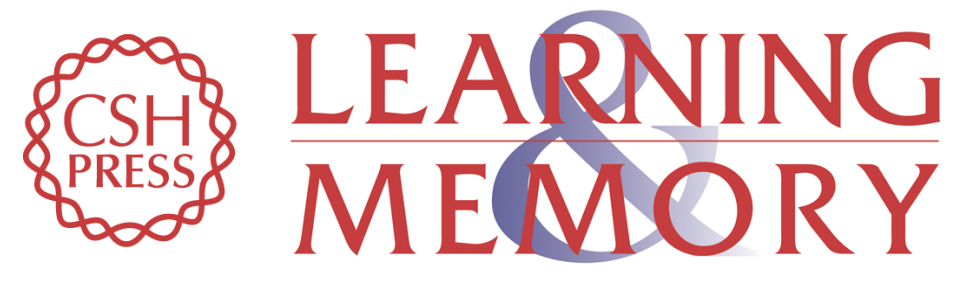

\section{Role of proteasome-dependent protein degradation in long-term operant memory in Aplysia}

Lisa C. Lyons, Jacob S. Gardner, Catherine E. Gandour, et al.

Learn. Mem. 2017, 24:

Access the most recent version at doi:10.1101/lm.043794.116

References This article cites 68 articles, 29 of which can be accessed free at: http://learnmem.cshlp.org/content/24/1/59.full.html\#ref-list-1

Creative This article is distributed exclusively by Cold Spring Harbor Laboratory Press for the Commons License first 12 months after the full-issue publication date (see

http://learnmem.cshlp.org/site/misc/terms.xhtml). After 12 months, it is available under a Creative Commons License (Attribution-NonCommercial 4.0 International), as described at http://creativecommons.org/licenses/by-nc/4.0/.

Email Alerting Receive free email alerts when new articles cite this article - sign up in the box at the Service top right corner of the article or click here. 